\title{
The Uniqueness of Newborn Health Care in The Batak Toba Community
}

\author{
Sri Rahayu Yusnita Situmorang, ${ }^{1, a, \#}$, Sri Rahayu Sanusi ${ }^{2, b}$, Fikarwin Zuska, ${ }^{3, c}$, R. Kintoko Rochadi ${ }^{2, d}$ \\ \& Etti Sudaryati ${ }^{2, e}$ \\ ${ }^{1}$ Magister Program School Department of Public Health Faculty, University of North Sumatera, Medan, Indonesia \\ ${ }^{2}$ Public Health Faculty, University of North Sumatera, Medan, Indonesia \\ ${ }^{3}$ Anthropology Department, University of North Sumatera, Medan, Indonesia \\ e-mail: ${ }^{\text {a\# }}$ sri.rahayu.yusnita2984@gmail.com \\ \#Corresponding Author \\ Whatsapp Number $\{+62-82166990820\}$
}

\section{ARTICLE HISTORY}

Received: 22 March 2019

Revised: 20 April 2019

Accepted: 26 June 2019

Copyright $\odot 2019$ Authors \& Published by IIES Independent. This is an open-access article distributed under the terms of the CC-BY-SA License.

\section{ABSTRACT}

This study aims to delve deeper into the uniqueness of newborn care applied by the Batak Toba Community. This research was conducted with a qualitative design using a phenomenological approach, data collection was done by in-depth interviews and observations to 8 informants in Tanjung Bunga Village, Pangururan District, Samosir Regency. The results showed the perspective of the Batak Toba Society regarding the care of newborns from maternal delivery assistance facility, umbilical cord care, children's nutritional needs, child hygiene, martataring/marsilusilu and eating with family as thanksgiving and showing joy because a child had been born inside family. Traditional practices are carried out in accordance with religion, values and beliefs adopted by the Batak Toba family. Traditionally, the practice of welcoming newborns beneficial to the health of children, especially newborns. However, medically, the traditional practices given will have a positive or negative impact on newborns, so health workers are expected to provide assistance and socialization regarding the tradition of welcoming newborns to suit the needs and health of newborns.

Keywords: Neonatal Care; Batak Culture; Umbilical Cord Care; Tradition

How to Cite: Situmorang, S.,R.,Y., Sanusi, S.,R., Zuska, F., Rochadi, R.,K., \& Sudaryati, E. (2019). The Uniqueness of Newborn Health Care in The Batak Toba Community. International Journal of Advances in Social and Economics, 1 (2), 79-88.

\section{Introduction}

Newborns are individuals who still adapt to their initial life outside the womb so that they are still vulnerable to various health problems. Parents, especially mothers, in addition to feeling happy with the birth of a child, will also feel anxious about the care of the newborn medically and traditionally according to the needs of the baby. The practice of caring for and welcoming newborns differs according to religion, tradition, beliefs and values adopted by the family, for example Javanese customs in the research in Pelalawan Regency, showing the tradition of the Mendhem from the father, Brokohan, Sepasaran, Puputan, Aqiqah which ends with the Selapanan tradition is carried out after a 40 day old baby (Widyaningrum, 2017). Each step in the ritual has the meaning and benefits and --- uniqueness of each. The Batak Toba community also has its own tradition in the care of newborns based on ancestral beliefs and advice which are still carried out by the people in Samosir District.

According to the Republic of Indonesia Ministry of Health's Basic Health Research carried out in 2013 even though labor by health workers both doctors and midwives had reached $87.1 \%$ while $10.9 \%$ of the people in Indonesia gave birth with baby shaman (Kemenkes, 2013). The Batak Toba community at the study site said they felt safer and more comfortable accompanied by a baby shaman or called Si Baso during childbirth because according to experience however the condition of the baby can be born 
without surgery, but in its current development the community has given birth by utilizing health facilities.

Research in Papua shows that baby shaman are more in Research in Papua shows that baby shaman are more in demand by the community because of their experience, traditions, psychology, economy and pregnancy conditions (Ramandey,2017), while the Meratus Dayak community in South Kalimantan states that baby shaman are well-known to the family, economically and cheaper besides that baby shaman also understand traditional rituals traditionally related to the care of newborns and can care for mothers and babies for 40 days postpartum (Sanjaya, 2016; Suryawati, 2007), besides that the relationship of trust to baby shaman makes the community safer and calm in choosing to give birth to a traditional birth attendant rather than a health worker (Ramandey, 2017; Suryawati, 2007).

Samosir Regency contributed to 103 deaths of children under 5 years of age in 2016 and ranked 20th in North Sumatra Province (Dinas Kesehatan Provinsi Sumatera Utara, 2016) with an infant mortality rate (IMR) of 15 per 1000 live births while under-five mortality rates 17 per 1000 live birth (Dinas Kesehatan Kabupaten Samosir, 2016). This shows that the Infant Mortality Rate in Samosir Regency has not yet reached the Infant Mortality Rate as SDG's target, which is 12 per 1000 live births, while the under five mortality rate target is 25 per 1000 live births that have been achieved by Samosir Regency. Based on the above data, efforts to control the deaths of infants aged 0-1 years are important to be improved and maintained by various strategies (Dinkes Kabupaten Samosir, 2016).

Another note that needs to be considered is the highest prevalence of deaths of under five children in Pangururan District. Infant mortality (age $0-1$ years) as many as 21 people $(35.6 \%)$ and under five children 15 people (35.7\%). According to the Samosir District Health Office, the highest risk of complications and deaths of maternal mothers and newborns occurs in the period around labor (Dinkes Kabupaten Samosir, 2016). Possible causes of high infant mortality can be attributed to the trend of childbirth assistance carried out by health workers, which decreases every year, in 2012 births by health workers reached $90 \%$ coverage which declined until 2016 to $80 \%$ coverage, although this figure has reached the target of Dinas Kesehatan is 73\% (Dinkes Kabupaten Samosir, 2016).

Based on the above data, infant mortality needs to get serious attention because it shows that there are limited health services received by newborns up to 1 year of - age to meet their needs at the beginning of their lives so that research on newborn care is important to be able to dig about the perspective and behavior of the Batak Toba Community in providing care for babies from birth, so that by this research the factors that can caused high infant mortality at Pangururan Subdistrict can be found.

Based on the preliminary survey, Samosir Regency is "Bona Pasogit" which means the hometown of the Batak Toba Community, cultural practices in accordance with strong ancestral traditions are still carried out by the Community especially in baby care. Practices according to this tradition can have positive and negative effects on children's health (Kasnodiharjo, 2012; Foster, 2006). According to Helman (2007); Trostle (2007); Hruschka and Hadley (2008); Hahn and Inhorn (2009) that culture can be a cause, and contribute to relating to poor health (Dixon et al, 2013). Based on the background above the researcher were interested in conducting a study on the Uniqueness of the Care of Newborns in the Batak Toba Society.

\section{Method}

This study uses a qualitative design with a phenomenological approach that specifically expresses the phenomena that are built, interpreted and experienced by the people studied, in their interactions related to the social, cultural, political and physical environment that arise from experience, actions and situations where problems occur by using collected data (Ulin et al, 2016). This research is expected to provide an understanding of the care of newborns in accordance with the Perspective of the Batak Toba Society and explain the traditional and modern practices used and positive and negative effect to child health.

\section{Research Purposes}

The purpose of this study is to explore the perspective of the Batak Toba Society in the care of newborns. The specific aim is to understand the practice of newborn care applied by the Batak Toba Community and its impact on children's health. This research was conducted in Tanjung Bunga Village, Pangururan Subdistrict, Samosir Regency by conducting interviews and observations for 6 mothers who have children under the age of 1 year. The reason for choosing the location is because the people in this location still carry out child health practices, especially baby care in accordance with the thick Batak Toba tradition. 


\section{Key Informan}

This research was conducted on 6 mothers who have children under 5 years old as key informants and 2 supporting informants and as Si Baso or baby shaman and sister-in-law of one of the informants who were at home at the time of interview. All of key informants are selected using purposive sampling based on the following criteria:

- Batak Toba Community.

- Residence in Tanjung Bunga Village.

- Having children under 5 years old (Key Informant)

- People who are on location at the time of the interview.

- Can provide important information related to the topic of this research

- Willing to be a participant in this study.

\section{Research Procedures}

This research was conducted by in-depth interviews and observations with informants using interview guidelines but it is still possible to develop new topics that are more in-depth. The interview guide is used so that the interview is directed and systematic. This research was also conducted in several stages, namely the preparation stage, the implementation phase and the data recording stage.

\section{Preparation Phase}

The researcher collects the data needed based on previous research and the latest data related to research, arranges interviews, prepares to collect data to the field and makes rapport and arranges interviews.

\section{Implementation Phase}

The researcher reconfirmed the time and place of the interview then carried out an interview based on a predetermined agreement and used interview guidelines, moved the recording of the interview results into verbatim transcripts, analyzed the data and drew conclusions.

\section{Data Recording Stage}

The researcher made a special note on observational data, interesting and important interview topics and other data based on different sources related in this study.

\section{Data processing}

After the data collection is complete, the next activity is data analysis carried out with the first step, reading information, rereading the notes and reviewing the information collected, paying attention to quality and identifying patterns. The second step is to give the code that is done by the process of attaching labels to lines of text so that it can group and compare the same information or related information and apply the code to the data consistently and reliably. The third step is to make a detailed description by means of the text that has been given the code, to be observed and studied in each of their thematic areas, to show in detail the differences in and between themes using the display of data and notes and start developing hypotheses. The fourth step is to get a picture and then the researcher reduces extensive data into manageable measures, separating essential data from non-essential ones using a matrix or diagram to arrive at its essential theme. The fifth and final step is the interpretation of the data at this stage the researcher will find important meanings, ensure trust, give an interpretation of the overall findings of the study and present it narratively.

Data analysis is done by the process of data reduction, categorization, synthesis, and composing hypotheses. After analyzing the data, triangulation was carried out which aimed to reduce the bias so as to produce reliable truthful research using various methods such as triangulation of methods, triangulation between researchers, triangulation of data sources and triangulation of theories.

\section{Results and Discussion}

Table 1. Informan's Data

\begin{tabular}{|c|c|c|c|c|}
\hline $\begin{array}{l}\text { Informan } \\
\text { code }\end{array}$ & Initial/ Age & $\begin{array}{l}\text { Supporting } \\
\text { Informan }\end{array}$ & $\begin{array}{c}\text { Level of } \\
\text { Education }\end{array}$ & Job \\
\hline 1 & Mrs RN/42 & & $\begin{array}{l}\text { Junior High } \\
\text { school }\end{array}$ & Farmer \\
\hline 2 & Mrs RS/43 & & $\begin{array}{l}\text { Senior High } \\
\text { School }\end{array}$ & Farmer \\
\hline 3 & Mrs RS/23 & $\begin{array}{l}\text { Mrs. Y } \\
\text { (Sister in } \\
\text { law) }\end{array}$ & Primary School & Farmer \\
\hline 4 & Mrs MN/21 & $\begin{array}{l}\text { Mrs. D } \\
\text { (MN21 } \\
\text { Mothers, Si } \\
\text { Baso) }\end{array}$ & $\begin{array}{l}\text { Senior High } \\
\text { School }\end{array}$ & Farmer \\
\hline 5 & Mrs SS/37 & & $\begin{array}{l}\text { Senior High } \\
\text { School }\end{array}$ & Farmer \\
\hline 6 & Mrs LS/38 & & $\begin{array}{l}\text { Senior High } \\
\text { School }\end{array}$ & Farmer \\
\hline
\end{tabular}


Based on Table 1 we can see that 4 people (50\%) informants were mothers with a high risk of giving birth. During the interview, several informants were with other people at home and provided important information related to this study, Mrs. Y, namely RS23's sister in law and Mrs. D, parents of Mrs. MN21 and as a Si Baso at the research site. We can also see the level of education of more middle school informants, namely 4 people $(50 \%)$, so that it can be believed that maternal knowledge about newborn care is sufficient. The main work of the community in the research location is farmers.

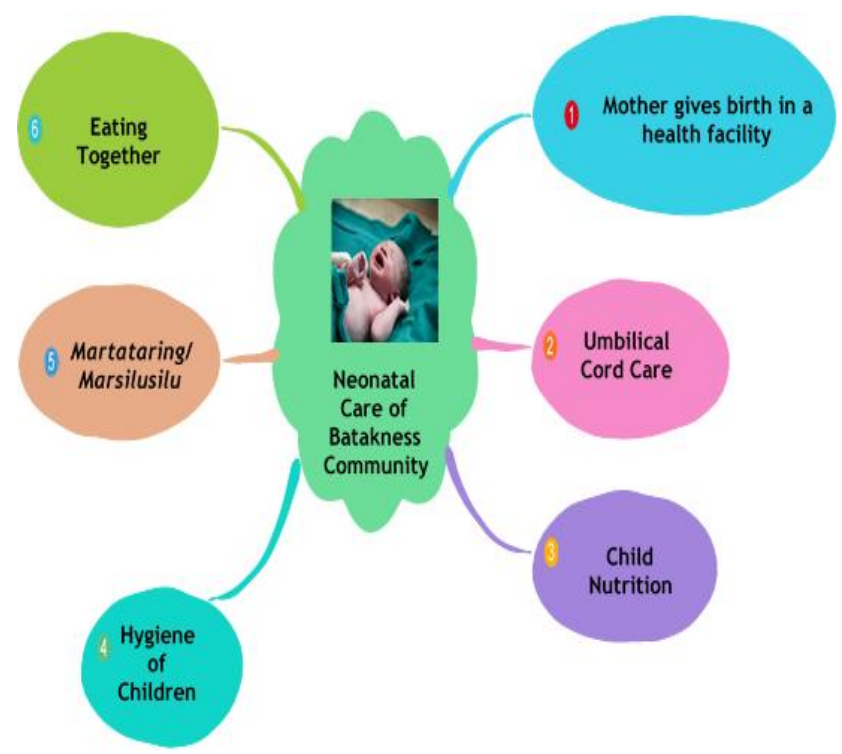

Figure 1 : Perspective of the Batak Toba Society on Newborn Care

Figure 1 above illustrates the perspectives of the Batak Toba community about newborn care starting with Mothers giving birth to a health facility, umbilical cord care, child nutrition, hygiene of children, martataring/ marsilusilu and eating together as a sign of delight that a child has been born in family.

\section{Mothers gives birth in a health facility}

Based on the results of interviews, all mothers had delivered at a health facility. This is in accordance with Article 14 of the Minister of Health Number 97 of the Republic Indonesia (Kemenkes RI, 2014) in order to guarantee quality delivery services for safe mothers and babies. Research on the selection of labor practices by mothers in Jepara in 2007 in 60 people was influenced by husbands, parents and grandmothers who were considered experienced, the results showed that as many as $63.3 \%$ of mothers had been assisted by midwives, and $18.4 \%$ of mothers were helped by traditional birth attendants or baby shaman (Suryawati, 2007).
An interview with the Village Midwife said that there were still several families of patients who called her to help with childbirth at home. Cases like this occur in mothers who postpone their arrival to the health facility on the grounds that there are still jobs at home or in the fields even though the birth signs have come out. Childbirth will run smoothly and without problems if the mother who is giving birth has awareness and needs from her own to deliver safely and the Health Officer is willing to carry out every procedure in this regulation as well as possible to guarantee the safety of the mother and baby. Considerations for going to health facility when the sign of giving birth has come are geographical location which is a hilly area, a long distance between the house to the health center and the transportation that will be used which must be well prepared.

Information found that after giving birth the mother is only in the Puskesmas for 3 to 4 hours. The Village Midwife justifies the statement and states that it depends also on the condition of the mother whether a labor problem occurs. In addition, the time of arrival of the mother to give birth is also a consideration for the midwife, if the mother comes in the evening the mother will return home tomorrow morning. This is not in accordance with the regulations in Article 15 of the Indonesian Ministry of Health that postpartum health services that must be received by mothers for post-partum monitoring at least 6 hours up to 3 days (Kemenkes RI, 2014).

Travel conditions from the health facility to the homes of people who climb the hill and cannot be passed by vehicles such as cars to the front of the house cause the mother to have to walk, climb or carried by a stretcher to her house. Risks that can be labor complications such as bleeding and even the condition of babies who are still adapting to the environment outside the uterus will cause children vulnerable to hypothermia because of the cold mountain atmosphere and other health problems.

Mrs. RN42, Mrs MN21's mother parent namely Mother. D as a Si Baso and Mrs. RS23's sister-in-law, Mrs. Y expressed the community's rejection of regulations that require the community to deliver at health facilities, but they also provided information that the Village Midwife would deliver mother and baby to their home, but for further actions such as bathing the baby, taking care of the cord, the Village Midwife is willing to go anywhere as long as the patient's family wants to pick up and deliver the Village Midwife back to the Puskesmas. 
Based on the information above, the community has not yet realized the importance of safe and quality giving birth in health facilities. The place of delivery should have complete emergency equipment before referral if a problem occurs in childbirth. But the observations of the researchers found that oxygen was not yet available in health facilities even though oxygen was very useful as the main emergency equipment other than infusion and drugs leading to further referrals.

\section{Umbillical Cord Care}

Care of the umbilical cord according to the results of the study consisted of three parts, namely cutting the umbilical cord, planting a baby center or commonly called "anggi anggi" and storing the rest of the umbilical cord as medicine.

\section{Cut the Umbilical Cord}

New Baby Care Born in ancient times has been very different from today. That was said by Mrs. D as Si Baso at the research location. Mrs. D said that ancient people did not use the help of the Midwives when they gave birth to their children. Mrs. D will prepare for the birth of her child by calculating the interpretation of the date of giving birth. When the time of labor arrives, the mother will bring all the equipment closer together, so that the dependency or assistance expected of the people around is very minimal. The tools that need to be provided in addition to hot water to bathe the baby are equipment for cutting the baby's umbilical cord, namely a new razor/knife, sambilu or bamboo, the cord tie is "rambu of ulos" meaning the rope under the ulos which has been soaked with the hot water and then squeezed to keep it clean.

The step of cutting the umbilical cord is not different from the Pandiangan study (Pandiangan, 2011), only in the Pandiangan study, the informants used are $S i$ Baso (Baby Shaman) so that all statements given can describe how to cut the umbilical cord completely and in detail. Mrs. D, who also plays the role of Si Baso, said that cutting the umbilical cord of a newborn baby is done using bamboo or a razor blade, taken from the distance of the umbilical cord to be cut by 3 fingers and tied with "rambu ulos". However now most mothers have been assisted by Midwives in the Health Facilities when giving birth so that Midwife have their own procedures for cutting the umbilical cord.

\section{Planting the Umbilical Cord}

Planting a baby's umbilical is a special ritual that has different ways and meanings for various tribes and cultures such as the Meratus Dayak tribe, Javanese tribe in Jepara and Walsa tribe in Papua. The Meratus Dayak tribe considers that planting a baby's umbillical is an honor and should not be done carelessly. They will wash the baby's umbilical then before planting the baby's umbilical will be given leaves, knives, and shallots (Sanjaya, 2016) different from the Javanese in Jepara who wash the umbilical or namely "ari ari" first, prayed and put into containers from clay and then given flowers three colours, the container is closed and then buried in front of the house then it will be illuminated using teplok lights for 35 days (Widyaningrum, 2017; Suryawati, 2007). The Walsa tribe in Papua will first wash the placenta, then put it in plastic and then plant it underground (Ramandey, 2017).

The unique of Batak Toba community can be seen in the way to plant "anggi anggi" or baby's umbillical which is a special ritual that is carried out with the aim that the child can be comfortable for a week. The baby's umbilical was planted under a banana tree, but before planted, it was also put candlenut, rice one handful and kerosene into the container. Baby's umbilical are considered to be siblings or younger siblings of babies born (Widyaningrum,2017; Ramandey, 2017 ; Sanjaya, 2016) so that the Batak Toba community called "anggi anggi". The belief of the Batak Toba community about the baby's umbillical based on interviews if "anggi anggi" is not planted properly and then bitten by ants, the child will cry. According to the Batak Toba community, people who plant baby's umbillical do not the baby's father only, but also others who are experienced. while in Dayak tribe (Sanjaya, 2016) those who plant baby centers are grandmothers or mother's younger sisters (Ramandey, 2017).

\section{Umbilical Cord Storage}

Another uniqueness is that the umbilical cord is stored because it has many functions. Based on the results of interviews with Mrs. RS43, the rest of the child's umbilical cord will be made into a bracelet, dried first, then given jerango and should also be given a single garlic, but because single garlic is rare, it is not used anymore. All ingredients are put into black cloth, sewn and made into a bracelet which will be used when going out of the house. Mrs RS43's stated that the bracelet would disappear after the child becomes big. Bracelet containing umbilical cord can also be used as medicine, by immersing them in hot water and then giving them to child drinks. According to Mrs. RS23 the water that is supplied to children is only 1 spoon. 
The function of making bracelets from the umbilical cord is as an antidote to people who are unknown and have bad intentions towards children. In addition, the bracelet containing the umbilical cord is also used as a hot medicine and is used if the child has a difficult disease to recover, for the Walsa Tribe in Papua there is no special treatment for the cord that has broken off (Ramendey, 2017). "Puputan" or the breakdown of the umbilical cord will be used as a ceremony or festivity to ask for prayer so that the child is blessed by God and will be offered various offerings to ancient Javanese tribes, but nowadays the "Puputan" event will coincide with selapanan or curiosity.

Current technological developments have used cord blood stored in placental banks to treat malignancies such as blood cancer and other non-malignant diseases, even blood on the placenta (stem cells) has been used successfully in HIV AIDS patients to prolong their lives without having to consume ARVs every day by way of stem cells as transplasntasi immune system for sufferers (Pernet and Yadav, 2016). Stem cells can differentiate into various cells in the body (Dusko and Polak, 2011).

\section{Newborn Babies Food}

In this study feeding in newborns consists of 3 parts namely Early Breastfeeding Initiation (IMD), traditional practice of giving candlenut (Candlenut), Exclusive breastfeeding.

\section{Early Breastfeeding Initiation}

Early breastfeeding or so-called Early Breastfeeding Initiation (IMD) is a Global Indicator (Raharjo, 2015) done by skin to skin between mother and baby by putting the baby on the mother's body on his stomach and then the baby will creep looking for the mother's nipple to breastfeed. Based on the results of interviews with Village Midwives, early breastfeeding initiation was not carried out because only 1 person in charge and was focused on the birth of a baby's umbillical and sewing maternal wounds (if needed) and while the weather at the study location cold so as to prevent hypothermia, but after all conditions were good, the baby has been put on a new swaddle then the baby is given to the mother.

Efforts that can be done to anticipate cold weather is to give a hat to the baby and when the IMD lasts can be given a blanket (Raharjo, 2015). Mothers who deliver with sectio caesarea IMD are performed 30 minutes after the mother is aware. IMD can reduce the $22 \%$ risk of a baby dying before 1 month of age (Raharjo, 2015). In more detail, the IMD procedure is carried out shortly after the baby is born and the umbilical cord is cut and carried out at least one hour after delivery and should not be restricted cloth (Kementerian Kesehatan Republik Indonesia, 2018 ; Raharjo, 2015). Newborns in Indonesia in 2017 who received an Early Breastfeeding Initiation of less than 1 hour amounted to $73.6 \%$, this number experienced a significant increase where in 2016 Indonesia reached 42.7\%. Whereas for the Province of North Sumatra itself IMD coverage was $30.3 \%$ in 2016 and increased to $45.74 \%$ in 2017 with a target of $44 \%$ national Strategic Plan. so that since 2017 North Sumatra has reached the target (Kemenkes RI, 2018).

\section{Giving Candlenut or Gambiri}

Based on the results of interviews with informants, newborns will be given candlenut. The function of giving this candlenut cleanses the digestion of the baby from the dirt that is eaten while in the womb because the impurities that are not released will have an impact when the child is 8 months old, precisely when the child starts eating, the child's feces can be hard out. Candlenut is given to the child by chewing in advance that can be done not only by mother, Mrs RS43 chews the candlenut herself, and can also be done by the baby's grandmother or aunty, then given to the newborn baby 3-4 hours. The consistency of candlenut is given until it is like filtered porridge or become like saliva and then given directly to the baby's mouth. According to Mrs RS43 the gift of candlenut is one ritual's of the culture of Batak Toba community.

Candlenut or kemiri or Aleurites Mollucana (L) Willd is usually used for traditional medicines and food ingredients. Javanese people use candlenut to treat diarrhea and dysentery (Krisnawati et al, 2011), 50 $60 \%$ of candlenut seed content is oil (Arlene, 2013). Oil extracted from candlenut seeds contains irritants and can function as a laxative, besides which crushed pecan seeds can also be used as soap and are often used to stimulate hair growth.

\section{Exclusive Breastfeeding}

Candlenut given 3 to 4 hours after the birth of the baby automatically can cause the baby to fail exclusive breastfeeding. Based on the results of interviews, 2 mothers said that their children were exclusively breastfed, even though the mother had given bananas, oranges, avocado and water to their children before the age of 6 months, some mothers also said they had given formula milk because breast milk did not come out. Besides to cultural factors, failure in exclusive breastfeeding is due to the fact that mothers at the 
research location do not have sufficient knowledge about the definition of exclusive breastfeeding and its implementation.

Proper feeding since the newborn will increase the risk of higher malnutrition at a later stage of life. Giving inappropriate breastfeeding will also increase the growth of children is not appropriate, susceptible to infection and more at risk of death (World Health Organization, 2001).

\section{Hygiene of Children}

Based on the results of the interview, the newborn baby is not immediately bathed, according to $\mathrm{Ny}$. RN42 if the child cannot be bathed immediately, various things are conveyed by Mrs. D, according to his experience. In the past, Mrs. D will immediately bathe her baby after birth. Next, Mrs. RS43, Mrs. RS23, Mrs. MN21 and Mrs. SS37 will bathe their children twice a day, but if there is no water the child will be bathed once a day.

Water is one of the problems in the research location, because the springs are under the settlement so that the water cannot rise especially the research location is in the mountains. People get water from rainfall. Besides that they have to go down to the spring at the foot of the hill called "Ack Gaol", some use motorbike vehicles but more are on foot which will take a 15-minute journey from the "Aek Gaol" intersection to the spring, not to mention to go back to the village through a hiking trip, usually 1 person will bring 2 jerry cans of water, whereas in the dry season the community will buy water.

Based on interviews, informants complained about how they wanted to do hygiene such as defecating in the toilet, take a bath, washing clothes while there was no water, even to drinking them was difficult. The problem of hygiene is one of the impacts because there is no water.

\section{Marsilusilu Ritual}

The Martataring or Marsilusilu activity is an effort made by the Batak Toba community to make the body of the newborn baby and his mother warm by burning wood. so that according to Mrs RS43 statement that wood is an important item when giving birth. Martataring or Marsilusilu rituals after the baby is born contain a lot of meaning and trust to provide health to newborns so that rituals such as "Poda poda na tulus sian natua tua na jolo" or advice from ancestors are still done today. After the mother and baby returned from the health center with a note that the mother who gave birth by surgery should not be Marsilusilu or Martataring.

The fire ritual from "Tataring" or tungku consists of two activities, namely doing "Poda Poda na tulus sian natua tua na jolo" and "martataring/marsilusilu".

\section{Poda-poda na tulus sian na tua tua ritual}

The ritual of the "poda poda na sian na tua tua na jolo" or advice from the ancestors, is currently only carried out by some people who still want to do it. The reason was according to Mrs. D statement because the community had given birth in the midwife. However, 4 people (50\%) informants gave information that they were still carrying out this ritual.

The way to do this ritual is different according to the perceptions of each person, Mrs RS43 begins the ritual by burning green leaves onto the fire but according to Mrs RS23 which is burned into the fireplace is a flower. Then the baby is carried over 2 hands and then swings around the fire, then the person holding the baby will say a different spell, but it has the same meaning even Mrs RS23 cannot mention the mantra. The words in the mantra are:

"Lalo lalo lalo lalo, buat on begu, molo so i ho, di hami i” (Mrs RN42)

"Lalo lalo lalo lalo, buat on begu, molo so dibuat ho saonari, andigan pe unang buat“ (Mrs RS43).

\section{Meaning:}

(Lalo, Lalo, Lalo, lalo, Take this ghost, if you don't take the baby now, don't do it forever).

People who perform this ritual are people who are old or considered to have understood and have experience carrying out rituals such as grandma, mother's sister etc. Public perception about the cause of the disease will affect the efforts made by the person in maintaining their health (Foster, 2006).

\section{Martataring/Marsilusilu}

"Marsilusilu" or "Martataring" is continued by the mother for 1 month. For mothers who give birth with a surgery "Marsilusilu" not done. The baby will be with the mother for one month near the fireplace. However, based on the results of an interview with Mrs. RS23 that even though US child was born with an operation but still also carried out "marsilusilu" rituals made with long distances.

According to the informant, the impact that can occur if the mother is not "marsilusilu" is that if the child is 
older, the mother will feel cold quickly and her back will hurt.

\section{Eating Together}

Eating together with family is a ritual performed by the family as a thanksgiving and joy because a child has been born in the family.

\section{Conclusion}

a. The uniqueness of newborn care in the Batak Toba Community can be seen from several rituals carried out in accordance with the culture, tradition, beliefs and values adopted with the aim that the newborn baby gets the best support in the early life according to the baby's needs as follows:

1. Selection of the place of birth which shows that all informants chose to give birth in a health facility

2. Baby center care which consists of cutting the baby's umbillical, planting a baby's umbillical and storing the baby's umbilical cord because the baby's umbillical considered as "anggi anggi" or the baby's sister for Batak Toba community that having a close relationship with the baby can even be used as a cure for severe illness

3. Baby food consisting of the Early Breastfeeding Initiation, traditional practice of pecan giving and Exclusive Breastfeeding. Early initiation of breastfeeding is the provision of the first milk that has high protein and is needed by the baby, midwives initiate early breastfeeding $>1$ hour because they prioritize prevention of hypothermia in infants and avoid the occurrence of postpartum complications while only 1 person is assigned. Furthermore, the results of the study showed that 4 informants confirmed that they had given candlenut to the baby after 3-4 hours of birth of a baby which is one of the cultures in the Sitaotao area, this caused exclusive breastfeeding to fail

4. Hygiene of children, in the past labor delivery will be carried out by the mother and the Si Baso so that the baby will soon be bathed after birth, but currently the delivery assistance has been carried out by the midwife so that it has its own procedures. Water is a major problem in research locations that prevents people from carrying out clean behaviors, such as bathing, open defecation, daily needs at home

5. Marsilusilu which consists of two rituals, namely "Poda poda na tulus sian natua tua" which consists of rituals and incantations for babies performed on "tataring" or stoves as ancestral suggestions that are still carried out because of beliefs in spirits that can affect children's health. At present it is only done by people who want to run it because they have given birth in a midwife. The next ritual is that the mother will do Marsilusilu by bringing her mother and baby closer to the "tataring" for 1 month so that the body of the mother and baby are warm and the mother has strong bones. The impact of not doing this ritual is when you get older you will experience painful and cold bones.

b. Health workers and informants in this study are still carrying out some newborn care practices that are not in accordance with the condition of babies who are still adapting to the environment outside the uterus so that it will pose a risk for babies who are still vulnerable to experiencing health problems :

1. The Health Officer has returned the postpartum mother and newborn baby back home after 3-4 hours of birth, even though the condition of the mother still needs to receive postpartum services for at least 6 hours up to 3 days (Kemenkes, 2014), subsequent mountainous geographical conditions in the study location make the mother have to walk while climbing to get to the house in a weak condition because labor makes the mother experience the risk of bleeding, fatigue and so on, cold weather in mountainous areas also makes newborns who are still adapting to their environment at risk of hypothermia.

2. Initiation of early breastfeeding is also not carried out by health workers because of cold weather conditions and babies at risk of hypothermia. Health workers need to update information about the skin to skin method between mothers and babies who can provide natural warmth, to prevent hypothermia babies can be given hats and blankets after the baby have breastfeeding.

3. Traditional practices that are still practiced by the community at the research location that have a negative impact are the administration of candlenut 3 or 4 hours after birth. The negative impact is that the exclusive breastfeeding program does not work on children. Giving candlenut to newborn is a culture and has a belief value for the Batak Toba Community. Accompany and sosialization by health workers regarding the best nutritional needs needed by babies and the content of breast milk that is suitable for the baby's needs for 6 months. This trust needs to be followed up by health workers, so 
that the Community is given socialization regarding Exclusive Breastfeeding.

4. Another impact of this candlenut is the pecan chewed before by the mother or other experienced person, will move the germs in the mouth of the person who chews the candlenut to the baby.

5. The storage of baby umbilical cord that is used as medicine is also a positive thing, the practice of providing infants with heat and other illnesses that are difficult to recover besides being done by the Batak Toba people is also carried out by the Javanese Tribe (Edward, 2018). The development of technology has made use of the umbilical cord for various treatments with the placental bank so that the baby's cord blood can be stored to be a cure for malignancy and non-heat and the latest findings in 2016 have become a cure for HIV AIDS sufferers.

\section{Recomendation}

Suggestions for this research are :

1. Health workers as the spearhead of health services in both urban and rural areas need to have good knowledge and skills so that they need training as a refresher and update the latest information about health in order to provide optimal services for the community.

2. Assistance and dissemination of exclusive breastfeeding and supplementary breastfeeding needs to be done to the community Provision of additional food in the form of candlenuts shortly after the baby is born is a culture that can have positive and negative impacts on infant health. It is necessary to have cross-sector and cross-program collaboration to change the behavior of these community.

3. Routine communication, information and education (IEC) implementation for Batak Toba communities in research locations to increase knowledge, willingness and ability to achieve a healthy life

4. The series of rituals carried out by the Batak Toba community in providing newborn care is one of the local wisdom of the community so that the government needs to document it, so that it does not disappear along with the times and technology.

\section{References}

Austin, J., Stevenson, H., Wei-Skillern, J., (2006). Social and commercial entrepreneurship: same, different, or both? Entrepreneurship: Theory and Pratice Journal, da Baylor University, Estados Unidos, volume 30, número 1, páginas 1-22, Janeiro de.

Arlene, Ariestya. (2013). Ekstraksi Kemiri dengan Metode Soxhlet dan Karakterisasi Minyak Kemiri, Jurnal Teknik Kimia USU, Vol 2, No. 2

Dinas Kesehatan Provinsi Sumatera Utara. (2016).Profil Dinas Kesehatan Provinsi Sumatera Utara Tahun 2016, Medan

Dinas Kesehatan Kabupaten Samosir., 2016, Profil Kesehatan Kabupaten Samosir : Samosir

Dixon, Jane., Banwell, Cathy., Ulijaszek, Stanley (2013) When Culture Impact Health, The Australian National University, Elsevier

Dusko, I., Polak, M, J, (2011), Stem Cells in Regenerative Medicine : Introduction, British Medical Buletin 2011;98;117-126 Doi : 10.1093/bmb/Idr012

Edward, Muhammad. (2018). Jangan Buang Tali Pusat Bayi Anda, Khasiat tersembunyinya Bikin Tercengang, Koran Tribun Sumsel Terbit 25 Maret 2018 Pukul 09: 21 Diakses pada 18 Maret 2019 pada 15:44 Wib.

George, M Foster., Anderson, G, Barbara. (2006), Antropologi Kesehatan, Cetakan 1, Penerbit Universitas Indonesia (UI Press), Jakarta

Kasnodiharjo., Angkasawati, T, J. (2012). Upaya Pencegahan dan Penyembuhan Penyakit Pada Bayi dan Anak Berdasarkan Konsepsi Budaya, Jurnal Ekologi Kesehatan Vol 12 No. 2, Juni 2013 : 140 151

Kemenkes RI. (2004). Keputusan Menteri Kesehatan RI Nomor 450 Tentang Pemberian ASI Secara Eksklusif pada Bayi di Indonesia, Jakarta, Kemenkes RI

Kemenkes RI, (2009), Undang Undang Kesehatan Republik Indonesia, Jakarta, Kemenkes RI

Kemenkes RI, (2013), Riset Kesehatan Dasar Tahun 2013, Badan Penelitian dan Pengembangan Kesehatan Kemenkes RI, Jakarta: Kemenkes RI

Kemenkes RI (2014), Permenkes RI Nomor 97 Tahun 2014 Tentang Pelayanan Kesehatan Masa Sebelum Hamil, Masa Hamil, Persalinan, Dan Masa Sesudah Melahirkan, Penyelenggaraan Pelayanan Kontrasepsi, Serta Pelayanan Kesehatan Seksual, Jakarta, kemenkes RI 
Kemenkes RI (2018). Profil Kesehatan Indonesia Tahun 2017, Kementerian Kesehatan RI, Jakarta

Krisnawati, B., Kallio, M., Kanninen, M. (2011). Aleurites Mollucana (L) Willd ; Ekologi, Silvikultur dan Produktivitas, Bogor, CIFOR.

Pandiangan, F, J. (2011). Perawatan Bayi Baru Lahir Menurut Perspektif Budaya Suku Batak Toba di Kecamatan Pangururan Kabupaten Samosir

Pernet, O., Yadav, S.S., An, D,S, (2016), Stem Cell Based Therapist for HIV AIDS Adv. Drug Deliv. Rev, (2016). http://dx.doi.org/10.1016/j.addr.2016.04.027

Raharjo, B. B. (2015). Momentum Emas Pembentukan SDM Berkualitas: Kajian Sosial Budaya Inisiasi Menyusu Dini dan ASI Eksklusif di Masyarakat Kendal Jawa Tengah, Satya Wacana University Press, Salatiga

Ramandey, S., Romauli, S., Niu, F. (2017). Study of Treatment of Pregnancy and Childbirth in Waris District, Keerom Reency, Province of Papua, Indonesia International Journal of Science and Research Volume 6 Issue 7 July 2017, P 1592-1601

Sanjaya, R,M., Ilmi B., Marlinae, L. (2016). Kajian Perilaku Kesehatan Dukun Terhadap Ibu dan Bayi Setelah Melahirkan Suku Asli Dayak Meratus Kalimantan Selatan, Jurnal Berkala Kesehatan, Vol 2, No. 1, Nov 2016 hal 1-8

Suryawati, C. (2007). Faktor Sosial Budaya dalam Praktik Perawatan Kehamilan, Persalinan dan Pasca Persalinan (Studi di Kecamatan Bangsri Kabupaten Jepara), Jurnal Promosi Kesehatan Indonesia, Vol 2, No. 1 Jnauari 2007

Ulin Pricilla R, Robinson Elizabeth T, Tolley Elizabeth E. (2016b). Qualitative Methods in Publich Health : a field guide for applied research second edition, San Fransisco: Jossey Bass

WHO. (2001). Complementary feeding: report of the global consultation, and summary of guiding principles for complementary feeding of the breastfed child, Geneva, Switzerland

Widyaningrum, L. (2017). Tradisi Adat Jawa Dalam Menyambut Kelahiran Bayi, JOM Fisip Vol 4 No. 2 Oktober 2017. 